\title{
The Role of History in International Business in Southern Europe
}

\begin{abstract}
This article examines first of all two aspects of the increasing role of history in international business: history as a source of research methods and history as an underpinning for international business theory. Second, the authors present key themes related to international business in Southern Europe in the last two centuries, as analyzed in the other articles of the special issue devoted to this theme in this special issue of the Journal of Evolutionary Studies in Business.
\end{abstract}

Keywords: International Business; Southern Europe; Joint Ventures; Alliances; Multinationals.

\section{Introduction}

There have been many calls to incorporate history into international business research including both "history as evidence" (Jones and Khanna 2006) and "History as a proving ground for international business research" (Buckley (2009)). Examining the long run in international business is increasingly at the forefront of current research (Fitzgerald 2015).

Corresponding author. E-mail: p.j.buckley@lubs.leeds.ac.uk

Received 06 April 2016 - Accepted 06 June 2016

This is an Open Access article distributed under the terms of the Creative Commons Attribution-Non-Commercial-No Derivatives License (http://creativecommons.org/licenses/by-nc-nd/4.0/), which permits non-comercial re-use and distribution, provided the original work is properly cited, and is not altered or transformed in any way. 
It is notable that not only is international business increasingly turning to history as a source of evidence ("process" research is increasingly salient (Welch and Paavilainen-Montymaki 2014), but also other areas of business research are becoming more historicised (a key example is organisation theory (Clark and Rowlinson 2004; Decker 2013).

This article examines two aspects of the increasing role of history in international business history as a source of research methods and history as an underpinning for international business theory. It takes for granted the role of history as evidence.

\section{History as a source of research methods}

Buckley (2016) suggested that four key research methods could, with profit, be more intensively applied to international business research. These are (1) source criticism, (2) time series analysis (3) comparative (historical) methods and (4) counterfactual analysis. In addition, history has much to add on the key methodological question of 'the unit of analysis'.

\section{Source Criticism}

International business researchers too often take "texts" at face value. "Texts" to international business researchers include secondary statistics, company financial statements, interviews with executives and policy makers, minutes of meeting and speeches. Trustworthiness is often taken for granted. All sources including oral history, artefacts and documents must be tested for authenticity and their authority, provenance and internal reliability and be subject to criticism - preferably from multiple sources. Critical text analysis includes the following questions. When was the text produced? Where was it produced? By whom was it produced? What pre-existing material influenced the text? Does it have integrity and credibility? In international business, there is often the question of language to be factored in to analysis - 
has the document been back - translated and are all the nuances understood? Often it is possible to shed illumination on texts by a dyadic approach - interviewing both parent and subsidiary, licensor and licensee, principal and outsourcing agent, management and unions, in order to get multiple viewpoints (this approach has become mandatory for publication in the top journals in international business).

There is also the question of what the extant archive omits. Jones (1998) makes this point in respect of company archives and excluded material may be important in achieving a rounded analysis. This point is well made in "subaltern studies", highlighting the excluded voices from (mainly) colonial narratives (Ludden 2001).

\section{Time Series Analyses}

The long run (and long standing) effects in international business are well documented (Chitu, Eichengreen and Mehl 2013). Process research is also an attempt to focus on the importance of sequencing in establishing causality (Pettigrew 1997). This contrasts with variance approaches' that exclude a time dimension (Easterlin 2013). Many cross-sectional approaches cannot capture causality.

\section{Comparative Methods}

Three classic comparative methods are across space (geographic comparison), across time (historical comparison) and against a carefully specified alternative state of the world (counterfactual comparison) (Buckley, Pass and Prescott 1992). International business, almost by definition, concentrates on across space (across nations), in most analysis and the multinational enterprise is a perfect vehicle for this because "the firm" is held constant whilst space is varied in comparing units of an international firm. This helps to highlight the impact 
of locational and cultural variations in the strategy of the firm. Historical research therefore adds another dimension of variation. The doyen of business historians, Alfred Chandler, described his use of detailed historical case studies as generating 'non-historically specific generalisations' (Chandler 1984). These were, ironically, highly location specific being drawn exclusively from the USA. The comparative geographical and historical methods give rich variation, essential for fine grained analysis, which is exactly what its advocates claim.

\section{Counterfactual Analysis}

The third key comparator is controversial - this is to construct a theoretically plausible alternative state of the world (alternative scenario) with which to compare observations of the existing state of affairs in order to evaluate decisions against 'what might have been'. This type of analysis has a long provenance in international business as 'the alternative position' in the analysis of foreign direct investment, asking the question "what would have happened if the FDI had not taken place'.

The key problem is to specify the alternative. In FDI there are three alternatives - no investment, investment by a domestic (home) firm or investment by a different foreign investor. Usually, the question of a different foreign investor is not considered, although it can have interest - does it matter if a foreign investment is Chinese owned rather than Spanish owned (in the UK for instance)? This is a subtly different question from comparing an FDI with a domestic investment focussing on strategic and cultural differences among nationalities of foreign investor.

Normally the question is asked relative to no investment or to a domestic investment (Reddaway 1968; Steuer 1973; Cairncross 1953). This fits with a tradition in economics where cost is defined as 'opportunity cost' - the real cost of the best alternative foregone, so 
this does not stretch the bounds of conventional economic thinking. Where the alternative is less easy to specify then arguments can be made on this designation and counterfactual analysis is not so straightforward - although it can be rewarding as a 'thought experiment' (Fogel 1964; Casson 2009).

\section{The Unit of Analysis}

International business has a challenging issue for researchers in the choice of unit of analysis (Buckley and Lessard 2005). Investigations can be at the level of the individual manager, the decision making body (the Board), the firm, the national economy, the region (EU), or the world economy. In today's world of networked multinationals (Buckley 2011; Buckley and Ghauri 2004) it can also be at the level of the network (the global factory) or the value chain. History, of course, has similar issues. Proponents of microhistory suggest that historical analysis at the smallest level (person, small group, local community, village) is the only way to detect key phenomena - and to do "total history" (Zeitlin 2007, 28).

This move away from larger scale national or political history has to account - like all choices of units of analysis - with interactions from all the other levels. Are not individual managers subject to company strategies, national policies, workplace, national and company cultures?

\section{History as an underpinning for international business theory}

Historians have long faced the challenges of understanding, comprehending and interpreting the mental structures of past societies. This exactly parallels the contextual difficulties of IB scholars interpreting the cognitive matrices of "other" cultures. As Solzhenitsyn said: "How can you expect a man who's warm to understand a man who's cold?" (Solzhenitsyn 1962). 
Two particularly approaches to this problem in history are the Annales school and 'Subaltern studies'. The Annales school emphasise the mental structures or mentalités of past societies. The Historian's Craft (Bloch 1954) is subject to revision over time. Historians from different periods, or from different countries, religions and cultures will ask different questions of the archive and will read its sources in different ways. There is however an issue about the ultimate purpose of history - is it to unveil 'the truth' or to understand the different perspectives (truths) of the various participants? Subaltern studies attempt to re-interpret the experience of colonialism by seeking to replicate the history of those excluded from conventional sources on which standard narratives are based ('subalterns'). Historians are familiar with the pitfalls that rise from taking archive material at face value. Many documents do not survive, or were never created (Jones 1998). In addition, the creation of an archive inevitably involves a selection process and the selectors may be subject to bias towards, or away from, particular genders, creeds, political groups, nations, regions, races, classes or belief systems. This is the basis for research on 'subaltern studies' (Ludden 2001). Archive records may also not cover particular issues or questions (Moss 1997; Belich 2009; Decker 2013; Schwarzkopf 2012).

One example of differences in context is time: specifically liturgical (sacred) time versus mechanical clock time. These systems of time are contrasted by the opening of the English Parliament "by tradition the Parliament of 1386 would have convened on the first Monday after the feast of St. Jerome, but now it was announced for October 1, 1386" (Strohm 2014, 155). This also applied to the computation of the year. "For most people in England it was the ninth year of King Richard, second of that name - an effect of computing the years by regnal time, or the space of a King's reign - but for purposes of parliamentary record keeping, it was 
now 1386" (Strohm 2014, 155). Until 1376 Parliament moved by "the stately measures of liturgical time, convening at half time, as somewhere between eight and nine o'clock. But for the previous decade it had convened by mechanical or clock time, at 8:00 in the morning" (Strohm 2014, 155). Liturgical time is cyclical - it marks time in relation to a holy festival and repeats annually. Regnal time, marking the location of the year in a given monarch's name, presumes continuity, tradition, inevitability, even divine sanction, of the status quo. With clock time come notions of linearity, progress, change and uncertainty in contrast to the certainty of repetition in liturgical time. "The new, mechanical systems of temporal measurement bespoke a commitment not just to accurate measurement but also to pragmatic assessment and an empirical view of political and social issues" (Strohm, 2014, 156). The shift from church's time to merchant's time, practical and measured, is a profound contextual change (Le Goff 1982).

\section{The Contribution of History to International Business Theory}

Given these challenges, the contribution of history to international business theorising has several components.

First, historical research focuses attention to long run versus short run theorising. Internalisation theory is the basis of a long-run theory of the multinational enterprise, comparing the net advantages of the firm versus the market as methods of organising economic activities (Buckley and Casson 1976). In contrast, John Dunning's (2000, 2001) eclectic theory incudes an ownership (O) component in the OLI (ownership, location, internalisation) explanation of the activities of MNEs that has to be defined in the short (or at least the medium) run (Casson 1987). This distinction aligns to some extent with the contrast between "strategy" and tactics (Freedman 2013). 
Second, historical research reminds us that theories are often time-bound in their relevance and applicability. A good example is Vernon's (1966) "Product Cycle Hypothesis" which was an excellent predictor of 1960s, 1970s and possibility 1980s outward foreign direct investment by US multinationals - to Europe in research of markets and to resource rich countries in search of primary inputs. The causality of this model was undermined by the growth of MNEs from Japan, Europe and later from emerging markets. Vernon's attempt to recast the theory in a less time-bound mode, focusing on oligopolistic market structures was considerably less satisfying as a coherent theory (Vernon 1979). It is possible that today's theories specifically aimed at explaining outward foreign direct investment from emerging markets may provide to be similarly timebound (e.g. Matthews 2002).

Similarly, the time horizon of theorising into the future has to be borne in mind. How long are the predictions of theory expected to hold? This of course relates to the structure of the theory, the exogenous variables and those factors held constant in the model. Sadly, there is often a disregard for the historical context in which theories operate, or are expected to operate.

Fourth, the role of expectations is often not explicit in international business theory. Expectations, and speculation on the formation of expectations can be a major element in decision making - including the strategic decisions of firms. History is an important determinant of expectation - the future is often held to resemble the past. Modelling of international business decision making and theories of the determinants of corporate policy could be underpinned by a greater awareness of historical reality. 


\section{International Business in Southern Europe: Crossing Boundaries Between Business History and International business}

The articles in this special issue are a combination of revised papers presented in a workshop at the University of Barcelona the $24^{\text {th }}$ of November of 2016, and invited papers. The theoretical and methodological approaches are diverse, from Entrepreneurship, International Business, and Business History. Their common aim is to provide readers of this journal a synthetic survey of old and new themes related to Foreign Direct Investment and Multinationals in Southern Europe, in a historical perspective. Three articles in particular present a long-term overview of the most outstanding scholarly contributions about the presence of foreign multinationals, and the evolution of domestic multinationals between the nineteenth century and the twentieth century, in three countries: Italy (Veronica Binda), Spain (Adoración Álvaro and Núria Puig), and Greece (Ioanna Sapfo Pepelasis and Dimitrios Varvaritis). Three articles provide in-depth case study approaches that focus on historical problems of alliances and knowledge transfer between multinationals of Late Developed and Developed Countries, and the liability of outsidership involved in the internationalization of companies in Spain: the case of the Spanish subsidiary of the French Renault (Tomás Fernández de Sevilla), and two Chinese subsidiaries (Felix Barahona, Fariza Achcaoucaou, Paloma Miravitlles) operating in Spain. And the case of the strategic alliance of the Spanish Telefónica in a European semiconductor corporation, European Silicon Structures ES2 (Àngel Calvo). The relevance of Schumpeterian entrepreneurs and efficient networks in Southern European countries, to overcome enormous technological and financial gaps with more developed and protected innovative neighbours, is highlighted in all the articles of the special issue, with a particularly useful overview of theories and contributions in this regard in the 
article by Águeda Gil, Ricardo Zozimo, Elena San Román, and Sarah L. Jack. Their role in developing international domestic companies has been historically outstanding in the late developed Southern European countries. A final research topic which is analyzed in this special issue is the intensity, evolution, and different internal composition and economic spillovers of foreign direct investors in Greece (Ioanna Sapfo Pepelasis and Dimitrios Varvaritis), Portugal (Álvaro Ferreira Da Silva), Italy (Verónica Binda), and Spain (Adoración Álvaro and Nuria Puig, Tomás Fernández de Sevilla). All the articles agree that quantitative approaches shed light, despite problems of quality and reliability of the historical records, on the participation of local investors with foreign investors in the first joint-stock companies that developed physical infrastructures and strategic industrial sectors and services in Southern Europe. The authors provide abundant evidences about the debates that since the nineteenth century the presence of foreign investors awakened among the national political and economic elites in Spain, Italy, Greece, or Portugal. They provide sound evidences that internationalization, inward or outward has been historically evaluated by some scholars as intrinsically helping to develop backward economic sectors, or intrinsically reducing the competitiveness of the local entrepreneurs. More needs to be studied, but this special issue is one of the first opportunities to learn in a synthetic way, from outstanding scholars in the field, about international business in an interdisciplinary perspective, for the Southern nations of Europe. We only hope that this special issue can contribute to a better understanding and learning about the complexities of the historical process of internationalization in these territories. Also, to promote new research that makes the knowledge go forward. 


\section{Acknowledgments}

Financial support from the Spanish Ministerio de Economía y Competitividad, research project HAR2013-41453-P helped present first drafts of the articles included in this special issue, in a workshop held at the University of Barcelona the $24^{\text {th }}$ Nov 2015.

Funds from the University of Barcelona received financed technical support for the copyediting of this issue.

\section{References}

Belich, James. 2009. Replenishing the Earth: The Settler Revolution and the Rise of the Angle-World 1783-1939. Oxford: Oxford University Press.

Bloch, Marc. 1954. The Historian's Craft. Translated by Peter Putman. UK: Manchester University Press.

Buckley, Peter J. 2009. "Business History and International Business." Business History 51 (3): 307333.

Buckley, Peter J. 2011. "International Integration and Coordination in the Global Factory." Management International Review 51 (2): 269-283.

Buckley, Peter J. (2016). "Historical Research Approaches to the Analysis of Internationalisation." Management International Review 56 (5/6).

Buckley, Peter J., and Mark Casson. 1976. The Future of the Multinational Enterprise. London: Macmillan.

Buckley, Peter J., and Pervez N. Ghauri. 2004. "Globalisation, economic geography and the strategy of multinational enterprises." Journal of International Business Studies 35 (2): 81-98.

Buckley, Peter J., and Donald R. Lessard. 2005. "Regaining the Edge for International Business Research.” Journal of International Business Studies 36 (6): 595-599.

Buckley, Peter J., C. L. Pass, and Kate Prescott. 1992. "The Internationalization of Service Firms: A Comparison with the Manufacturing Sector." Scandinavian International Business 1 (1): 39-56.

Casson, Mark. 1987. The firm and the market: Studies on multinational enterprise and the scope of the firm. Oxford: Basil Blackwell.

Casson, Mark. 2009. The World's First Railway System. Oxford: Oxford University Press.

Cairncross, Alexander K. 1953. Home and Foreign Investment 1870-1913. Cambridge: Cambridge University Press. 
Chandler, Alfred D. 1984. "Comparative Business History." In Enterprise and History: Essays in Honour of Charles Wilson, edited by D. C. Coleman and Peter Mathias, 3-26. Cambridge: Cambridge University press.

Chitu, Livia, Barry Eichengreen, and Arnaud J. Mehl. 2013. "History, Gravity and International Finance." National Bureau of Economic Research Working paper 18697. Washington D.C.

Clark, Peter, and Michael Rowlinson. 2004. "The treatment of history in Organisation Studies: Towards an 'Historic Turn'?" Business History 43 (3): 331-352.

Decker, Stephanie. 2013. "The silence of the archive: post-colonialism and the practice of historical reconstruction from archival evidence." Management and Organisational History 22 (1): 27-48.

Dunning, John H. 2000. "The eclectic paradigm as an envelope for economic and business theories of the MNE.” International Business Review 9:163-90.

Dunning, John H. 2001. "The Eclectic (OLI) Paradigm of International Production: Past, Present and Future." International Journal of the Economics of Business 8 (2): 173-90.

Easterlin, Richard A. 2013. "Cross Sections are History.” IZA, Discussion Paper 7341.

Fitzgerald, Robert. 2015. The Rise of the Global Company, Multinationals and the Making of the Modern World. Cambridge: Cambridge University Press.

Fogel, Robert W. 1964. Railroads and American Economic Growth: Essays in Econometric History. Baltimore, Maryland: The Johns Hopkins Press.

Freedman, Lawrence. 2013. Strategy. Oxford: Oxford University Press.

Jones, Geoffrey G. 1998. "Company History and Business History in the 1990s." University of Reading Discussion Papers in Economics and Management (Series A). 383.

Jones, Geoffrey, and Tarun Khanna. 2006. Bringing History (Back) into International Business. Journal of International Business Studies 37 (4): 453-468.

Le Goff, Jaques. 1982. Time, work and culture in the Middle Age. Chicago: University of Chicago Press.

Ludden, David, ed. 2001. Reading Subaltern Studies: Critical History, Contested Meaning and the Globalization of South Asia. London: Anthem Press.

Mathews, John A. 2002. Dragon multinational: A new model for global growth. Oxford and New York: Oxford University Press.

Moss, Michael. 1997. "Archives, the Historian and the Future." In Companion to Historiography, edited by Michael Bentley, 937-948. London: Routledge.

Pettigrew, Andrew M. 1997. "What is a processual analysis?" Scandinavian Journal of Management 13 (4): $337-348$ 
Reddaway, William B., S. J. Potter, and Christopher T. Taylor. 1968. Effects of UK Direct Investment Overseas: Final Report. Cambridge: Cambridge University Press.

Schwarzkopf, Stefan. 2012. "Why business historians need a constructive theory of the archive." Business Archives 105 (November): 1-9.

Solzhenitsyn, Aleksandr. 1962. One day in the life of Ivan Denisovich. London: Sphere Books.

Strohm, Paul. 2014. The Poet's Tale: Chaucer and the Year that Made the Canterbury Tales. London: Profile Books.

Steuer, Max David, et al. 1973. The Impact of Foreign Direct Investment on the U.K. London: HMSO. Vernon, Raymond. 1966. "International trade and international investment in the product cycle." Quarterly Journal of Economics 80 (2): 190-207.

Vernon, R. 1979. "The Product Cycle Hypothesis in a New International Environment." Oxford Bulletin of Economics and Statistics 41 (4): 255-67.

Welch, Catherine, and Eriikka Paavilainen-Mäntymäki. 2014. "Putting Process (Back) In: Research on the Internationalization Process of the Firm." International Journal of Management Reviews 16 (1): $2-23$

Zeitlin, Jonathan. 2007. "The Historical Alternatives Approach." In The Oxford Handbook of Business History, edited by Geoffrey Jones and Jonathan Zeitlin, 120-140. Oxford: Oxford University Press.

This is an Open Access article distributed under the terms of the Creative Commons Attribution-Non-Commercial-No Derivatives License (http://creativecommons.org/licenses/by-nc-nd/4.0/), which permits non-comercial re-use and distribution, provided the original work is properly cited, and is not altered or transformed in any way. 